\title{
Pengaruh Kualitas Produk, Impulse Buying dan Electronic Word of Mouth (EWOM) terhadap Keputusan Pembelian pada Produk Smartphone Merek Oppo di Kota Denpasar
}

\author{
I Kadek Rupayana ${ }^{1}$ \\ I Wayan Suartina ${ }^{2}$ \\ IA. Mashyuni ${ }^{3}$ \\ 1,2,3 Fakultas Ekonomi Bisnis dan Pariwisata Universitas Hindu Indonesia \\ Email : rupayana23@gmail.com
}

\begin{tabular}{|l|l|l|}
\hline Diterima: 8 Desember 2020 & Direvisi: 12 Desember 2020 & Disetujui: 22 Desember 2020 \\
\hline
\end{tabular}

\begin{abstract}
The purchase decision is the final stage that determines the viability of a product, because when the consumer has decided, it means the product was purchased by the consumer. The purpose of this study was to determine the effect of product quality, impulse buying, and electronic word of mouth on purchasing decisions for OPPO brand smartphone products in Denpasar. The sample in this study were 135 respondents with the sampling technique used was purposive sampling. The data analysis technique used is multiple linear regression. The results of the analysis show that each of the independent variables, namely the effect of product quality, impulse buying, and electronic word of mouth parisally and simultaneously has a positive and significant effect on purchasing decisions for OPPO brand smartphone products in Denpasar.
\end{abstract}

Keywords: product quality, impulse buying, and electronic word of mouth on purchasing decisions

\begin{abstract}
ABSTRAK
Keputusan pembelian adalah tahap akhir yang menentukan keberlangsungan hidup suatu produk, karena ketika konsumen sudah memutuskan maka itu berarti produk tersebut dibeli oleh konsumen. Tujuan penelitian ini adalah untuk mengetahui pengaruh kualitas produk, impulse buying, dan electronic word of mouth terhadap keputusan pembelian produk smartphone merek OPPO di Kota Denpasar. Sampel dalam penelitian ini adalah sebanyak 135 responden dengan teknik sampling yang digunakan adalah purposive sampling. Teknik analisis data yang digunakan adalah regresi linear berganda. Hasil analisis menunjukkan bahwa masing-masing variabel bebas yaitu pengaruh kualitas produk, impulse buying, dan electronic word of mouth secara parisal dan simulta berpengaruh positif dan signifikan terhadap keputusan pembelian produk smartphone merek OPPO di Kota Denpasar.
\end{abstract}

Kata kunci : kualitas produk, impulse buying, dan electronic word of mouth terhadap keputusan pembelian

\section{PENDAHULUAN}

Kebutuhan akan alat komunikasi seperti telepon seluler (handphone) atau smartphone sendiri selalu mengalami peningkatan dari tahun ketahun terutama untuk jenis-jenis handphone atau smartphone dengan merek-merek tertentu. Hal ini disebabkan karena para produsen smartphone selalu berlomba-lomba untuk menciptakan berbagai fitur-fitur baru dalam dunia telekomunikasi. Keberhasilan Oppo dalam merajai pangsa pasar smartphone di Indonesia 
ditentukan oleh strategi komunikasi yang tepat dalam memasarkan produk mereka sehingga memudahkan konsumen untuk menentukan keputusan pembelian.

Ada tiga tiga aktivitas yang berlangsung dalam proses keputusan pembelian oleh konsumen yaitu, rutinitas konsumen dalam melakukan pembelian, kualitas yang diperoleh dari suatu keputusan pembelian dan komitmen atau loyalitas konsumen untuk tidak akan mengganti keputusan yang sudah biasa di beli dengan produk pesaing (Hahn (2002). Terdapat tiga faktor yang dapat mempenagruhi keputusan pembelian konsumen di antaranya kualitas produk, impulse buying, dan electronic word of mouth. Kotler dan Amstrong (2010:273), mendefinisikan kualitas produk adalah totalitas fitur dan karakteristik produk atau jasa yang bergantung pada kemampuannya untuk memuaskan kebutuhan yang dinyatakan atau tersirat. Penelitian yang dilakukan oleh Rosvita Dua Lembang (2010) menunjukkan kualitas produk berpengaruh positif dan signifikan terhadap keputusan pembelian.

Menurut Mowen dan Minor (2001), Impulse Buying adalah tindakan membeli yang dilakukan tanpa memiliki masalah sebelumnya atau maksud atau niat membeli yang terbentuk sebelum memasuki toko. Schiffman dan Kanuk (2007) impulse buying merupakan keputusan yang emosional atau menurut desakan hati. Penelitian dari Linda Ayu Rahmawati (2017) dan Penelitian Rodita Yulinda, dkk. (2018) menunjukkan impulse buying berpengaruh positif dan signifikan terhadap keputusan pembelian.

Thurau et al, (2004), mengemukakan bahwa electronic word of mouth adalah pernyataan positif ataupun negatif yang dilakukan oleh pelanggan potensial ataupun mantan pelanggan tentang produk atau perusahaan, yang ditujukan untuk banyak orang atau lembaga via internet. Gruen (2006), mendefinisikan EWOM sebagai sebuah media komunikasi untuk saling berbagi informasi mengenai suatu produk atau jasa yang telah dikonsumsi antar konsumen yang tidak saling mengenal dan bertemu sebelumnya. Dalam penelitian milik Novita Sari, dkk. (2017) menunjukkan hasil bahwa Electronic Word of Mouth berpengaruh positif terhadap keputusan pembelian. Penelitian lain dari Adeliasari, Vina dan Thio (2014) menunjukkan hasil bahwa EWOM memiliki pengaruh positif dan signifikan terhadap keputusan pembelian.

Tujuan penelitian ini adalah (1) untuk mengetahui pengaruh kualitas produk terhadap keputusan pembelian, (2) untuk mengetahui pengaruh Impulse Buying terhadap keputusan pembelian smartphone Oppo di Kota Denpasar, (3) untuk mengetahui pengaruh Electronic Word of Mouth (EWOM) terhadap keputusan pembelian, dan (4) untuk mengetahui pengaruh kualitas 
produk, Impulse Buying dan Electronic Word of Mouth (EWOM) secara simultan terhadap keputusan pembelian smartphone Oppo di Kota Denpasar.

\section{TELAAH LITERATUR DAN HIPOTESIS}

\section{Keputusan Pembelian}

Ada tiga tiga aktivitas yang berlangsung dalam proses keputusan pembelian oleh konsumen yaitu ( Hahn (2002)) Rutinitas konsumen dalam melakukan pembelian, Kualitas yang diperoleh dari suatu keputusan pembelian, dan komitmen atau loyalitas konsumen untuk tidak akan mengganti keputusan yang sudah biasa di beli dengan produk pesaing. Menurut Basu Swastha dan Hani Handoko (1997), proses pengambilan keputusan pembelian suatu produk dapat digambarkan dalam tahapan- tahapan keputusan pembelian yaitu pengenalan masalah, pencarian informasi, evaluasi alternatif, pengambilan keputusan, dan perilaku pasca pembelian.

\section{Kualitas Produk}

Kotler (2010:273), mendefinisikan kualitas produk adalah totalitas fitur dan karakteristik produk atau jasa yang bergantung pada kemampuannya untuk memuaskan kebutuhan yang dinyatakan atau tersirat. Kualitas produk merupakan keseluruhan gabungan karakteristik produk yang dihasilkan dari pemasaran, rekayasa, produksi dan pemeliharaan yang membuat produk tersebut dapat digunakan memenuhi harapan pelanggan atau konsumen (Wijaya (2011:11).

\section{Impulse Buying}

Menurut Mowen dan Minor (2001) definisi pembelian impulsif (Impulse Buying) adalah tindakan membeli yang dilakukan tanpa memiliki masalah sebelumnya atau maksud atau niat membeli yang terbentuk sebelum memasuki toko. Intinya pembelian impulsif dapat dijelaskan sebagai pilihan yang dibuat pada saat itu juga karena perasaan positif yang kuat mengenai suatu benda. Schiffman dan Kanuk (2007 : 511) impulse buying merupakan keputusan yang emosional atau menurut desakan hati.

\section{Hipotesis}

Berdasarkan rumusan masalah dan landasan teori yang dikemukakan, maka dalam penelitian ini dapat dirumuskan hipotesis sebagai berikut :

H1 : Diduga kualitas produk berpengaruh positif dan signifikan terhadap keputusan pembelian Smartphone Oppo di Kota Denpasar.

H2 : Diduga impulse buying berpengaruh positif dan signifikan terhadap keputusan pembelian Smartphone Oppo di Kota Denpasar. 
H3 : Diduga electronic word of mouth (EWOM) berpengaruh positif dan signifikan terhadap keputusan pembelian Smartphone Oppo di Kota Denpasar.

H4 : Diduga kualitas produk, impulse buying dan electronic word of mouth (E-WOM) secara simultan berpengaruh positif terhadap keputusan pembelian Smartphone Oppo di Kota Denpasar.

\section{METODE PENELITIAN}

Dari penelusuran kajian pustaka dan hasil penelitian sebelumnya berdasarkan permasalahan yang diteliti, penelitian yang digolongkan pada penelitian asosiatif (hubungan), yaitu penelitian yang bertujuan untuk mengetahui pengaruh dari satu variabel, dua variabel atau lebih (Sugiyono (2017:5)). Metode ini digunakan untuk mengetahui hubungan antara variabel Kualitas Produk, Impulse Buying dan Electronic Word of Mouth (EWOM) terhadap Keputusan Pembelian pada smartphone Oppo di Kota Denpasar.

Gambar 1.

Kerangka Konseptual

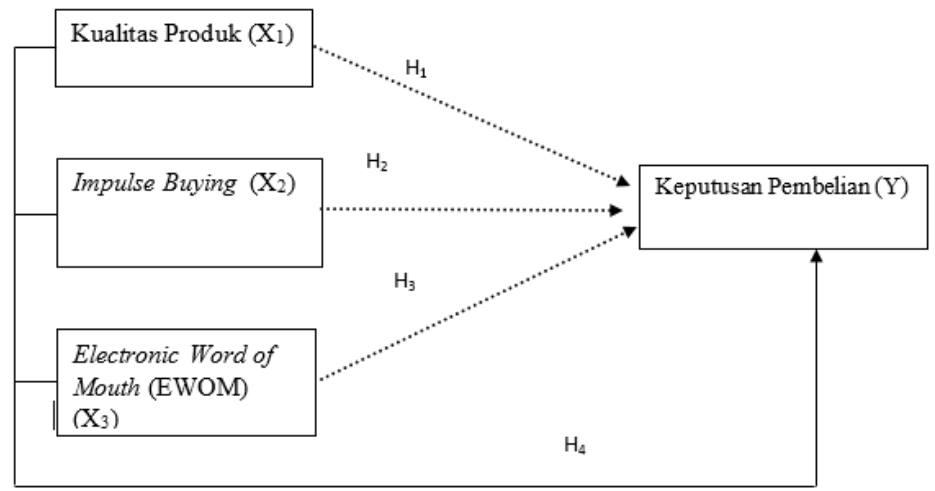

Dalam penelitian

ini yang menjadi populasi adalah konsumen yang sudah pernah membeli dan menggunakan smartphone Oppo. Populasi bersifat infinite karena jumlahnya tidak diketahui dengan pasti. Penentuan jumlah sampel dilakukan dengan metode 5 x jumlah idikator sehingga diperoleh sampel sebanyak 135 responden dan penentuan sampel dilakukan dengan metode purposive sampling. Pengumpulan data dilakukan dengan menggunakan metode observasi, wawancara, dokumentasi, kepustakaan, dan kuisioner. Skala pengukuran yang digunakan adalah dengan skala likert 5. Nilai dari skala likert yaitu, skor $1=$ sangat tidak setuju (STS), 2 = tidak setuju (TS), $3=$ netral $(\mathrm{N}), 4=$ setuju $(\mathrm{S})$, dan $5=$ sangat setuju (SS). Analisis regresi linear berganda dipilih sebagai alat analisis karena sesuai dengan hipotesis yang diajukan yaitu menguji pengaruh secara parsial dan simultan. 


\section{HASIL DAN PEMBAHASAN}

\section{Uji Instrumen Penelitian}

Hasil uji instrumen pada Tabel 1 menunjukkan bahwa seluruh item pernyataan adalah valid akrena memiliki nilai koefisien korelasi dengan skor total seluruh item pernyataan lebih besar dari 0,30 dan reliabel karena memiliki koefisien Cronbach's Alpha lebih dari 0,60

\section{Tabel 1. Hasil Uji Validitas dan Reliabilitas}

\begin{tabular}{|c|c|c|c|c|c|}
\hline \multirow[b]{2}{*}{ Variabel } & \multirow[b]{2}{*}{$\begin{array}{c}\text { Item } \\
\text { Pernyataan }\end{array}$} & \multicolumn{2}{|c|}{ Validitas } & \multicolumn{2}{|c|}{ Reliabilitas } \\
\hline & & $\begin{array}{c}\text { Koefisien } \\
\text { Korelasi }\end{array}$ & Ket. & $\begin{array}{c}\text { Cronbach's } \\
\text { Alpha }\end{array}$ & Ket. \\
\hline \multirow{8}{*}{$\begin{array}{l}\text { Kualitas Produk } \\
\qquad\left(\mathrm{X}_{1}\right)\end{array}$} & $\mathrm{X}_{1.1}$ & 0,433 & Valid & \multirow{8}{*}{0,728} & \multirow{8}{*}{ Reliabel } \\
\hline & $\mathrm{X}_{1.2}$ & 0,384 & Valid & & \\
\hline & $\mathrm{X}_{1.3}$ & 0,664 & Valid & & \\
\hline & $\mathrm{X}_{1.4}$ & 0,723 & Valid & & \\
\hline & $\mathrm{X}_{1.5}$ & 0,662 & Valid & & \\
\hline & $\mathrm{X}_{1.6}$ & 0,727 & Valid & & \\
\hline & $\mathrm{X}_{1.7}$ & 0,379 & Valid & & \\
\hline & $\mathrm{X}_{1.8}$ & 0,556 & Valid & & \\
\hline \multirow{7}{*}{$\begin{array}{l}\text { Impulse Buying } \\
\qquad\left(\mathrm{X}_{2}\right)\end{array}$} & $\mathrm{X}_{2.1}$ & 0,375 & Valid & \multirow{7}{*}{0,748} & \multirow{7}{*}{ Reliabel } \\
\hline & $\mathrm{X}_{2.2}$ & 0,392 & Valid & & \\
\hline & $\mathrm{X}_{2.3}$ & 0,677 & Valid & & \\
\hline & $\mathrm{X}_{2.4}$ & 0,365 & Valid & & \\
\hline & $\mathrm{X}_{2.5}$ & 0,777 & Valid & & \\
\hline & $\mathrm{X}_{2.6}$ & 0,564 & Valid & & \\
\hline & $\mathrm{X}_{2.7}$ & 0,439 & Valid & & \\
\hline \multirow{8}{*}{$\begin{array}{c}\text { Electronic Word of } \\
\text { Mouth }\left(\mathrm{X}_{3}\right)\end{array}$} & $\mathrm{X}_{3.1}$ & 0,45 & Valid & \multirow{8}{*}{0,689} & \multirow{8}{*}{ Reliabel } \\
\hline & $\mathrm{X}_{3.2}$ & 0,494 & Valid & & \\
\hline & $\mathrm{X}_{3.3}$ & 0,49 & Valid & & \\
\hline & $\mathrm{X}_{3.4}$ & 0,773 & Valid & & \\
\hline & $\mathrm{X}_{3.5}$ & 0,727 & Valid & & \\
\hline & $\mathrm{X}_{3.6}$ & 0,424 & Valid & & \\
\hline & $\mathrm{X}_{3.7}$ & 0,393 & Valid & & \\
\hline & $\mathrm{X}_{3.8}$ & 0,446 & Valid & & \\
\hline \multirow{4}{*}{$\begin{array}{c}\text { Keputusan } \\
\text { Pembelian (Y) }\end{array}$} & $\mathrm{Y}_{1}$ & 0,381 & Valid & \multirow{4}{*}{0,79} & \multirow{4}{*}{ Reliabel } \\
\hline & $\mathrm{Y}_{2}$ & 0,591 & Valid & & \\
\hline & $\mathrm{Y}_{3}$ & 0,37 & Valid & & \\
\hline & $\mathrm{Y}_{4}$ & 0,612 & Valid & & \\
\hline
\end{tabular}

Sumber : data diolah, 2020

\section{Karakteristik Responden}

Dari 135 responden dibuatkan suatu karakteristik berdasarkan jenis kelamin, usia, pendidikan terakhir, dan lama pemakaian Smartphone Oppo. 
Tabel 2. Karakteristik Responden

\begin{tabular}{clcc}
\hline Kriteria & \multicolumn{1}{c}{ Pilihan } & Jumlah (orang) & Persentase (\%) \\
\hline \multirow{4}{*}{ Jenis Kelamin } & Laki-Laki & 79 & 58,52 \\
& Perempuan & 56 & 41,48 \\
& Total & 135 & 100,00 \\
\hline \multirow{3}{*}{ Usia } & $\leq 30$ & 87 & 64,44 \\
& $31-40$ & 33 & 24,44 \\
& $41-50$ & 12 & 8,89 \\
& $>50$ & 3 & 2,22 \\
& Total & 135 & 100,00 \\
\hline \multirow{4}{*}{ Pendidikan } & S2 & 8 & 5,93 \\
& S1 & 67 & 49,63 \\
& SMA/K & 60 & 44,44 \\
& Total & 135 & 100,00 \\
\hline \multirow{2}{*}{ Lama pemakaian } & $1-5$ tahun & 132 & 97,78 \\
& $6-10$ tahun & 3 & 2,22 \\
& Total & 135 & 100,00 \\
\hline
\end{tabular}

Sumber : data diolah, 2020

Berdasarkan jenis kelamin menunjukkan bahwa sebagian besar responden yaitu sebanyak 79 orang berjenis kelamin laki-laki dan hanya 56 orang perempuan, berdasarkan usia besar responden yaitu sebanyak 87 orang masih berusia di bawah 30 tahun, responden berusia 31 sampai dengan 40 tahun sebanyak 33 orang, responden yang berusia 41 sampai dengan 50 tahun sebanyak 12 orang, dan responden yang berusia lebih dari 50 tahun sebanyak 3 orang. Berdasarkan pendidikan sebagian besar responden yaitu sebanyak 67 orang berpendidikan terakhir strata 1, sebanyak 60 orang masih di jenjang SMA/K, dan 8 orang responden berpendidikan terakhir strata 2. Sebagian besar pengguna Smartphone Oppo telah memakai 1-5 tahun sebanyak 132 orang, sedangkan yang memakai 6-10 tahun hanya 3 orang.

\section{Deskripsi Variabel Penelitian}

Data pada Tabel 3, jawaban responden mengenai keputusan pembelian memperoleh nilai rata-rata sebesar 3,76 dan masuk dalam kriteria baik. Hal tersebut menunjukkan bahwa keputusan pembelian pada produk smartphone merk Oppo diterapkan dengan baik. 
Tabel 3. Deskripsi Variabel Keputusan Pembelian

\begin{tabular}{|c|c|c|c|c|c|c|c|}
\hline \multirow{2}{*}{ Pernyataan } & \multicolumn{5}{|c|}{ Distribusi jawaban } & \multirow{2}{*}{$\begin{array}{c}\text { Rata - } \\
\text { rata }\end{array}$} & \multirow{2}{*}{ Ket } \\
\hline & 1 & 2 & 3 & 4 & 5 & & \\
\hline $\begin{array}{l}\text { Saya sangat yakin dengan kualitas produk } \\
\text { Smartphone Oppo. }\end{array}$ & 3 & 5 & 36 & 63 & 28 & 3,8 & Baik \\
\hline $\begin{array}{l}\text { Saya sudah biasa membeli produk-produk } \\
\text { dari Smartphone Oppo. }\end{array}$ & 3 & 5 & 40 & 64 & 23 & 3,73 & Baik \\
\hline $\begin{array}{l}\text { Saya selalu memberikan rekomendasi } \\
\text { kepada teman dan keluarga untuk membeli } \\
\text { produk Smartphone Oppo. }\end{array}$ & 1 & 2 & 41 & 60 & 31 & 3,87 & Baik \\
\hline $\begin{array}{l}\text { Saya akan kembali melakukan pembelian } \\
\text { produk Smartphone Oppo. }\end{array}$ & 5 & 18 & 22 & 65 & 25 & 3,64 & Baik \\
\hline Total & & & & & & 3,76 & Baik \\
\hline
\end{tabular}

Sumber : data diolah, 2020

Data pada Tabel 4 menunjukkan bahwa jawaban responden mengenai kualitas produk memperoleh nilai rata-rata sebesar 3,84 dan masuk dalam kriteria baik. Hal tersebut menunjukkan bahwa kualitas produk diterapkan dengan baik.

Tabel 4. Deskripsi Variabel Kualitas Produk

\begin{tabular}{|c|c|c|c|c|c|c|c|}
\hline \multirow{2}{*}{ Pernyataan } & \multicolumn{5}{|c|}{ Distribusi jawaban } & \multirow{2}{*}{$\begin{array}{c}\text { Rata - } \\
\text { rata }\end{array}$} & \multirow{2}{*}{ Ket } \\
\hline & 1 & 2 & 3 & 4 & 5 & & \\
\hline $\begin{array}{l}\text { Smartphone Oppo merupakan produk dengan } \\
\text { kinerja yang sangat baik. }\end{array}$ & - & 6 & 35 & 41 & 53 & 4,04 & Baik \\
\hline $\begin{array}{l}\text { Smartphone Oppo merupakan produk yang } \\
\text { dapat diandalkan untuk menjalankan fungsi } \\
\text { utamanya. }\end{array}$ & - & 12 & 38 & 50 & 35 & 3,8 & Baik \\
\hline $\begin{array}{l}\text { Smartphone Oppo memiliki berbagai macam } \\
\text { fitur yang menarik. }\end{array}$ & 3 & 8 & 28 & 56 & 40 & 3,9 & Baik \\
\hline $\begin{array}{l}\text { Smartphone Oppo memiliki daya tahan yang } \\
\text { sangat tahan lama dan tidak mudah rusak. }\end{array}$ & 3 & 8 & 28 & 57 & 39 & 3,9 & Baik \\
\hline $\begin{array}{l}\text { Kinerja produk smartphone Oppo sesuai } \\
\text { dengan apa yang tercantum pada deskripsi } \\
\text { produk. }\end{array}$ & 5 & 11 & 43 & 49 & 27 & 3,61 & Baik \\
\hline Apabila terjadi kerusakan maka smartphone & & & & & & & \\
\hline $\begin{array}{l}\text { Oppo bisa diperbaiki dengan cepat di service } \\
\text { center Oppo dimana saja. }\end{array}$ & 1 & 13 & 30 & 63 & 28 & 3,77 & Baik \\
\hline $\begin{array}{l}\text { Smartphone Oppo memiliki desain atau } \\
\text { tampilan produk yang indah. }\end{array}$ & 1 & 10 & 25 & 54 & 45 & 3,98 & Baik \\
\hline $\begin{array}{l}\text { Kualitas dari produk smartphone Oppo sangat } \\
\text { dirasakan saat pemakaian sehari-hari }\end{array}$ & - & 9 & 40 & 61 & 25 & 3,76 & Baik \\
\hline $\begin{array}{l}\text { Total } \\
\end{array}$ & & & & & & 3,84 & Baik \\
\hline
\end{tabular}

Sumber : data diolah, 2020

Data pada Tabel 5 menunjukkan bahwa jawaban responden mengenai Impulse Buying memperoleh nilai rata-rata sebesar 3,91 dan masuk dalam kriteria baik. Hal tersebut menunjukkan bahwa Impulse Buying dijalankan dengan baik. 
Tabel 5. Deskripsi variabel impulse buying

\begin{tabular}{|c|c|c|c|c|c|c|c|}
\hline \multirow{2}{*}{ Pernyataan } & \multicolumn{5}{|c|}{ Distribusi jawaban } & \multirow{2}{*}{$\begin{array}{c}\text { Rata }- \\
\text { rata }\end{array}$} & \multirow{2}{*}{ Ket } \\
\hline & 1 & 2 & 3 & 4 & 5 & & \\
\hline $\begin{array}{l}\text { Saya cenderung mempunyai dorongan atau } \\
\text { hasrat yang sangat kuat untuk berbelanja suatu } \\
\text { produk. }\end{array}$ & 1 & 6 & 26 & 60 & 42 & 4,01 & Baik \\
\hline $\begin{array}{l}\text { Saya mempunyai kecendrungan untuk } \\
\text { berbelanja berbagai macam hal saat suasana } \\
\text { hati positif. }\end{array}$ & 1 & 7 & 37 & 46 & 44 & 3,93 & Baik \\
\hline $\begin{array}{l}\text { Saya sangat suka untuk berkeliling toko } \\
\text { meskipun hanya karena ingin melihat-lihat } \\
\text { saja. }\end{array}$ & 4 & 14 & 22 & 57 & 38 & 3,82 & Baik \\
\hline Saya merasakan kesenangan saat berbelanja & 1 & 7 & 30 & 65 & 32 & 3,89 & Baik \\
\hline $\begin{array}{l}\text { Saya mempunyai waktu luang yang sangat } \\
\text { banyak. }\end{array}$ & 2 & 6 & 30 & 62 & 35 & 3,9 & Baik \\
\hline $\begin{array}{l}\text { Saya memiliki cukup uang untuk melakukan } \\
\text { pembelian berbagai produk. }\end{array}$ & 1 & 10 & 19 & 56 & 49 & 4,05 & Baik \\
\hline $\begin{array}{l}\text { Saya cenderung melakukan pembelian secara } \\
\text { tiba-tiba tanpa perencanaan terlebih dahulu. }\end{array}$ & 3 & 7 & 37 & 57 & 31 & 3,79 & Baik \\
\hline Total & & & & & & 3,91 & Baik \\
\hline
\end{tabular}

Sumber : data diolah, 2020

Data pada Tabel 6 menunjukkan bahwa jawaban responden mengenai Electronic Word of

Mouth memperoleh nilai rata-rata sebesar 3.81 dan masuk dalam kriteria baik. Nilai rata-rata tertinggi jawaban responden ditunjukkan pada pernyataan "Jejaring sosial menyediakan berbagai macam informasi mengenai kualitas produk smartphone Oppo." sebesar 3,99; sedangkan nilai rata-rata terendah jawaban responden ditunjukkan pada pernyataan "Informasi mengenai smartphone oppo banyak tersedia di media sosial.” dengan nilai rata-rata sebesar 3,63.

Tabel 6. Deskripsi Variabel Electronic Word of Mouth

\begin{tabular}{|c|c|c|c|c|c|c|c|}
\hline \multirow{2}{*}{ Pernyataan } & \multicolumn{5}{|c|}{ Distribusi jawaban } & \multirow{2}{*}{$\begin{array}{l}\text { Rata- } \\
\text { rata }\end{array}$} & \multirow{2}{*}{ Ket } \\
\hline & 1 & 2 & 3 & 4 & 5 & & \\
\hline $\begin{array}{l}\text { Informasi mengenai smartphone oppo } \\
\text { banyak tersedia di media sosial. }\end{array}$ & 2 & 16 & 37 & 55 & 25 & 3,63 & Baik \\
\hline $\begin{array}{l}\text { Penjual produk Oppo sering melakukan } \\
\text { interaksi dengan pengguna media sosial. }\end{array}$ & 3 & 18 & 24 & 57 & 33 & 3,73 & Baik \\
\hline $\begin{array}{l}\text { Produk Smartphone Oppo memiliki banyak } \\
\text { ulasan dari para pengguna media sosial. }\end{array}$ & 4 & 12 & 30 & 60 & 29 & 3,73 & Baik \\
\hline $\begin{array}{l}\text { Produk smartphone Oppo mendapatkan } \\
\text { banyaka komentar positif dari para } \\
\text { pengguna media sosial. }\end{array}$ & 5 & 10 & 37 & 48 & 35 & 3,73 & Baik \\
\hline $\begin{array}{l}\text { Banyak pengguna media sosial yang } \\
\text { merekomendasikan produk smartphone } \\
\text { Oppo. }\end{array}$ & 2 & 5 & 27 & 69 & 32 & 3,92 & Baik \\
\hline $\begin{array}{l}\text { Situs jejaring sosial dari Oppo menyediakan } \\
\text { berbagai informasi yang dibutuhkan } \\
\text { pengguna jejaring sosial lainnya. }\end{array}$ & - & 12 & 28 & 64 & 31 & 3,84 & Baik \\
\hline $\begin{array}{l}\text { Jejaring sosial menyediakan berbagai } \\
\text { macam informasi mengenai kualitas produk } \\
\text { smartphone Oppo. }\end{array}$ & - & 9 & 25 & 59 & 42 & 3,99 & Baik \\
\hline $\begin{array}{l}\text { Jejaring sosial menyediakan informasi } \\
\text { mengenai harga yang ditawarkan untuk } \\
\text { produk smartphone Oppo. }\end{array}$ & 5 & 11 & 25 & 49 & 45 & 3,87 & Baik \\
\hline Rata-rata variabel & & & & & & & 3,81 \\
\hline
\end{tabular}


Sumber : data diolah, 2020

\section{Uji Asumsi Klasik}

Berdasarkan Tabel 7 dapat dilihat bahwa nilai Kolmogorov Sminarnov (K-S) sebesar 0,048, sedangkan nilai Asymp. Sig. (2-tailed) sebesar 0,200. Hasil tersebut mengindikasikan bahwa model persamaan regresi tersebut berdistribusi normal karena nilai Asymp. Sig. (2-tailed) 0,200 lebih besar dari nilai alpha 0,05 .

\section{Tabel 7. Hasil uji Normalitas}

\begin{tabular}{lc}
\hline & Unstandardized Residual \\
\hline $\mathrm{N}$ & 135 \\
Kolmogorov-Smirnov $Z$ & 0,065 \\
Asymp.Sig.(2-tailed) & 0,2 \\
\hline
\end{tabular}

Sumber : data diolah, 2020

Berdasarkan Tabel 8 dapat dilihat bahwa nilai tolerance dan VIF dari seluruh variable menunjukkan bahwa nilai tolerance untuk setiap variabel lebih besar dari 10 persen dan nilai VIF lebih kecil dari 10 yang berarti model persamaan regresi bebas dari multikolinearitas.

\section{Tabel 8. Hasil Uji Multikolinearitas}

\begin{tabular}{lcc}
\hline \multicolumn{1}{c}{ Variabel } & Tolerance & VIF \\
\hline Kualitas Produk (X1) & 0,985 & 1,015 \\
Impulse Buying (X2) & 0,991 & 1,009 \\
Electronic Word of Mouth (X3) & 0,994 & 1,006 \\
\hline
\end{tabular}

Sumber : data diolah, 2020

Pada Tabel 9 dapat dilihat bahwa nilai Sig. dari kualitas produk, impulse buying, dan electronic word of mouth masing-masing sebesar 0,839; 0,867 dan 0,927 Nilai tersebut lebih besar dari 0,05 yang berarti tidak terdapat pengaruh antara variabel bebas terhadap absolute residual. Dengan demikian, model yang dibuat tidak mengandung gejala heteroskedastisitas.

Tabel 9. Hasil Uji Heteroskedastisitas

\begin{tabular}{|c|c|c|c|c|c|c|}
\hline & \multirow[t]{2}{*}{ Model } & \multicolumn{2}{|c|}{$\begin{array}{l}\text { Unstandardized } \\
\text { Coefficients }\end{array}$} & \multirow{2}{*}{$\begin{array}{c}\text { Standardized } \\
\text { Coefficients } \\
\text { Beta }\end{array}$} & \multirow[t]{2}{*}{$\mathrm{t}$} & \multirow[t]{2}{*}{ Sig. } \\
\hline & & $\mathrm{B}$ & Std. Error & & & \\
\hline \multirow{4}{*}{1} & (Constant) & 1.838 & 1.477 & & 1.244 & .216 \\
\hline & Kualitas Produk & -.005 & .026 & -.018 & -.204 & .839 \\
\hline & Impulse Buying & -.006 & .035 & -.015 & -.168 & .867 \\
\hline & Electronic Word of Mouth & -.002 & .027 & -.008 & -.092 & .927 \\
\hline
\end{tabular}

Sumber : data diolah, 2020

\section{Analisis Regresi Linear Berganda}

Pengujian data dalam penelitian ini menggunakan teknik analisis regresi linear berganda. Perhitungan koefisien regresi linear berganda dilakukan dengan analisis regresi melalui software SPSS. 
Tabel 10. Hasil Analisis Regresi Linear Berganda

\begin{tabular}{lccc}
\hline \multicolumn{1}{c}{ Variabel } & $\begin{array}{c}\text { Nilai Koefisien } \\
\text { Regresi }\end{array}$ & t hitung & Nilai Signifikansi \\
\hline (Constant) & 11.898 & 4.756 & 0 \\
Kualitas Produk $\left(\mathrm{X}_{1}\right)$ & 0,046 & 1,049 & 0,03 \\
Impulse Buying $\left(\mathrm{X}_{2}\right)$ & 0,022 & 0,369 & 0,007 \\
Electronic Word of Mouth $\left(\mathrm{X}_{3}\right)$ & 0,037 & 0,815 & 0,042 \\
\hline F Statistik & & 3,621 & \\
Signifikansi & & 0,028 \\
\hline
\end{tabular}

Sumber : data diolah, 2020

Berdasarkan hasil analisis regresi linear berganda seperti yang disajikan pada Tabel 10, maka didapat nilai koefisien regresi 0,046 untuk variabel kualitas produk, impulse buying dengan nilai koefisien regresi 0,022 , dan electronic word of mouth dengan nilai koefisien regresi 0,037, sehingga dapat dituliskan model persamaan regresinya sebagai berikut:

$$
\mathrm{Y}=11,898+0,046 \mathrm{X}_{1}+0,022 \mathrm{X}_{2}+0,037 \mathrm{X}_{3}+e
$$

1. Persamaan regresi diatas menunjukkan nilai konstanta sebesar 11,898 yang berarti apabila X1, X2 dam X3 sama dengan 0 maka nilai Y adalah sebesar nilai konstanta yaitu 11,898.

2. Nilai 0,046 adalah nilai koefisien regresi untuk variabel kualitas produk yang artinya kualitas produk memiliki pengaruh positif terhadap keputusan pembelian jadi bila kualitas produk naik satu satuan maka nilai keputusan pembelian akan naik juga sebesar 0,046.

3. Nilai 0,022 adalah nilai koefisien regresi untuk variabel impulse buying yang artinya impulse buying memiliki pengaruh positif terhadap keputusan pembelian jadi bila impulse buying naik satu satuan maka nilai keputusan pembelian juga akan naik sebesar 0,022.

4. Nilai 0,037 adalah nilai koefisien regresi untuk variabel electronic word of mouth yang artinya electronic word of mouth memiliki pengaruh positif terhadap keputusan pembelian jadi bila electronic word of mouth naik satu satuan maka nilai keputusan pembelian juga akan naik sebesar 0,037 .

\section{Analisis Koefisien Determinasi}

Berdasarkan hasil analisis regresi linear berganda seperti yang disajikan pada Tabel 11 didapat nilai determinasi total sebesar 0,614 mempunyai arti bahwa sebesar 61,4 persen variasi keputusan pembelian dipengaruhi oleh variasi kualitas produk, impulse buying, dan electronic word of mouth sedangkan sisanya sebesar 38,6 persen dijelaskan oleh faktor lain yang tidak dimasukkan ke dalam model.

Tabel 11. Koefisien Determinasi

R Square $\quad 0,614$

Adjusted R Square

0,609

Sumber : data diolah, 2020 


\section{Uji Signifikansi Parsial (uji t)}

Uji t dilakukan untuk menjawab hipotesis 1, 2, dan 3 yang menyatakan bahwa masingmasing variabel bebas yaitu impulse buying $(\mathrm{H} 1)$, word of mouth $(\mathrm{H} 2)$, dan kualitas produk $(\mathrm{H} 3)$ berpengaruh positif dan signifikan terhadap keputusan pembelian. Hasil uji t dapat dilihat pada Tabel 10.

1. Pengaruh Kualitas Produk Terhadap Keputusan Pembelian Pada Produk Smartphone Merek Oppo Di Kota Denpasar

Berdasarkan hasil pengujian hipotesis, pengaruh kualitas produk terhadap keputusan pembelian dengan hasil (sig. t $0.030<0.05$ ) serta koefisien beta sebesar 0,046 menunjukan bahwa kualitas produk berpengaruh secara positif dan signifikan terhadap keputusan pembelian. Hal ini menunjukkan bahwa semakin baik kualitas produk yang dijual, maka akan meningkatkan keputusan pembelian pada produk smartphone merek oppo di kota Denpasar. Penelitian ini sesuai dengan penelitian yang dilakukan oleh Rosvita Dua Lembang (2010) pada penelitiannya yang berjudul "Analisis Pengaruh Kualitas Produk, Harga, Promosi, dan Cuaca terhadap Keputusan Pembelian Teh Siap Minum dalam Kemasan Merek The Botol Sosro" menunjukkan hasil bahwa kualitas produk berpengaruh positif dan signifikan terhadap keputusan pembelian terhadap Teh Botol Sosro. Begitu juga dengan penelitian Praba Sulistyawati (2010) dalam penelitiannya yang berjudul "Analisis Pengaruh Citra Merek dan Kualitas Produk terhadap Keputusan Pembelian Laptop Merek Acer di kota Semarang" menunjukkan hasil bahwa kualitas produk berpengaruh positif terhadap keputusan pembelian.

2. Pengaruh Impulse Buying Terhadap Keputusan Pembelian Pada Produk Smartphone Merek Oppo Di Kota Denpasar

Berdasarkan hasil pengujian hipotesis, pengaruh impulse buying terhadap keputusan pembelian dengan hasil (sig. t 0.007 < 0.05 ) serta koefisien beta sebesar 0,022 menunjukan bahwa impulse buying berpengaruh secara positif dan signifikan terhadap keputusan pembelian. Hal ini menunjukkan bahwa semakin tinggi impulse buying yang dimiliki konsumen, maka akan meningkatkan keputusan pembelian pada produk smartphone merek oppo di kota Denpasar.

Penelitian ini sesuai dengan penelitian yang dilakukan Linda Ayu Rahmawati (2017) dalam penelitiannya yang berjudul "Pengaruh Diskon, Impulse Buying, dan Interior Display terhadap Keputusan Pembelian" menunjukkan hasil bahwa impulse buying berpengaruh positif dan signifikan terhadap keputusan pembelian. Begitu juga penelitian yang dilakukan 
oleh Rodita Yulinda, Dkk (2018) dalam penelitiannya yang berjudul "Pengaruh Promosi, Diskon, dan Impulse Buying terhadap Kepputusan Pembelian pada Indomaret cabang Rungkut Menanggal kota Surabaya" menunjukkan hasil bahwa impulse buying berpengaruh positif dan signifikan terhadap keputusan pembelian.

3. Pengaruh Electronic Word Of Mouth (Ewom) Terhadap Keputusan Pembelian Pada Produk Smartphone Merek Oppo Di Kota Denpasar

Berdasarkan hasil pengujian hipotesis, pengaruh electronic word of mouth (ewom) terhadap keputusan pembelian dengan hasil (sig. t $0.042<0.05$ ) serta koefisien beta sebesar 0,037 menunjukan bahwa electronic word of mouth (ewom) berpengaruh secara positif dan signifikan terhadap keputusan pembelian. Hal ini menunjukkan bahwa semakin baik electronic word of mouth (ewom) yang ada di lingkungan konsumen, maka akan meningkatkan keputusan pembelian pada produk smartphone merek oppo di kota Denpasar.

Penelitian ini sesuai dengan penelitian yang dilakukan oleh Vina dan Thio (2014), dalam penelitiannya yang berjudul "Electronic Word of Mouth (eWOM) dan Pengaruhnya terhadap Keputusan Pembelian di Restoran dan Kafe di Surabaya" menunjukkan hasil bahwa eWOM memiliki pengaruh positif dan signifikan terhadap keputusan pembelian. Begitu juga dengan penelitian yang dilakukan oleh I Made Dwijananda (2016) yang berjudul "Analisis Pengaruh Electronic Word of Mouth terhadap Proses Keputusan Pembelian" menunjukkan hasil bahwa eWOM berpengaruh terhadap peroses keputusan pembelian.

\section{PENUTUP}

\section{Simpulan}

Simpulan yang dapat diambil berdasarkan hasil analisis adalah sebagai berikut.

1. Kualitas produk berpengaruh positif dan signifikan terhadap keputusan pembelian. Karena hasil penelitian menunjukkan t sig sama dengan $0.030<0.05$ serta koefisien beta sebesar 0,046. Hal ini menunjukkan bahwa semakin baik kualitas produk yang dijual, maka akan meningkatkan keputusan pembelian pada produk smartphone merek oppo di kota Denpasar.

2. Impulse buying berpengaruh positif dan signifikan terhadap keputusan pembelian. Karena hasil penelitian menunjukkan t sig sama dengan $0.007<0.05$ serta koefisien beta sebesar 0,022. Hal ini menunjukkan bahwa menunjukan bahwa semakin tinggi impulse buying yang dimiliki konsumen, maka akan meningkatkan keputusan pembelian pada produk smartphone merek oppo di kota Denpasar.

3. Electronic word of mouth (ewom) berpengaruh secara positif dan signifikan terhadap keputusan pembelian. Karena hasil penelitian menunjukkan t sig sama dengan $0.042<0.05$ ) 
serta koefisien beta sebesar 0,037. Hal ini menunjukkan bahwa semakin baik electronic word of mouth (ewom) yang ada di lingkungan konsumen, maka akan meningkatkan keputusan pembelian pada produk smartphone merek oppo di kota Denpasar.

4. Nilai F signifikansi sama dengan $0,028<0,05$. Hal ini berarti secara simultan variabel kualitas produk, impulse buying, dan electronic word of mouth (ewom) berpengaruh signifikan terhadap keputusan pembelian pada produk smartphone merek oppo di kota Denpasar.

\section{Saran}

Adapun saran yang dapat diberikan berdasarkan hasil penelitian adalah sebagai berikut.

1. Perusahaan smartphone Oppo sebaiknya selalu menjaga kualitas produk, meningkatkan impulse buying dan memaksimalkan electronic word of mouth (eWOM) karena berdasarkan hasil penelitian membuktikan bahwa ketiga variabel tersebut memiliki pengaruh positif dan signifikan terhadap keputusan konsumen untuk membeli smartphone Oppo.

2. Perusahaan smartphone Oppo sebaiknya memperbaiki kinerja produk smartphone Oppo agar sesuai dengan apa yang tercantum pada deskripsi produk. Dengan kesesuaian antara kinerja produk dan deskripsi produk, diharapkan mampu meningkatkan keputusan pembelian smartphone Oppo.

3. Pada analisis deskriptif didapatkan hasil yang paling rendah dari variabel impulse buying adalah pernyataan "Saya cenderung melakukan pembelian secara tiba-tiba tanpa perencanaan terlebih dahulu" ini berarti perusahaan smartphone Oppo perlu membuat gagasan seperti promo di hari-hari tertentu untuk meningkatkan impulse buying konsumen.

4. Perusahaan smartphone Oppo sebaiknya menambah dan mengiklankan lebih banyak informasi mengenai smartphone oppo di media sosial. Dengan adanya penambahan informasi yang detail, diharapkan mampu meningkatkan keputusan pembelian smartphone Oppo.

5. Bagi peneliti berikutnya, sebaiknya menambahkan variabel-variabel lain dalam penelitian yang dapat mempengaruhi variabel keputusan pembelian, seperti variabel kepuasan, variabel daya tarik iklan, variabel persepsi harga, dan variabel lainnya, agar penelitian selanjutnya dapat digeneralisasi.

\section{REFERENSI}

A.F. Stoner. 2006. Manajemen Sumber Daya Manusia. Jakarta: Bumi Aksara

Adeliasari. 2014. Electronic Word-OF-Mouth (eWOM) dan Pengaruhnya terhadap Keputusan Pembelian di Restoran dan Kafe di Surabaya. Universitas Kristen Petra

Adhandayani, Amalia. 2018. Beda Budaya, Beda Pula Penyebab Belanja Impulsif. Dikutip pada tanggal 
https://www.kompasiana.com/amemalia/5c0fe798bde5752fd6427817/beda-budaya-bedapula-penyebab-belanja-impulsif

Astuti, P. R. 2008. Meredam Bullying 3 Cara Efektif Meredam K. P. A. (Kekerasan Pada Anak). Jakarta: Grasindo

Basu Swasta DH., dan T. Hani Handoko. 1997. Manajemen Pemasaran Modern, Liberty, Yogyakarta

Dua Lembang, Rosvita. 2010. Analisis Pengaruh Kualitas Produk, Harga, Promosi, dan Cuaca terhadap Keputusan Pembelian Teh Siap Minum merek Teh Botol Sosro. Undip

Dwijananda, I Made. 2016. Analisis Pengaruh Elesctronic Word of Mouth terhadap Keputusan Pembelian. Jurnal Manajemn, Vol 3 No. 1

Fazrin, Arini. 2019. Canalys: Top 5 Vendor Smartphone di Indonesia Q2 2019. Dikutip pada tanggal 01 februari 2020. Website: https://selular.id/2019/08/5-vendor-terbaik-diindonesial

Garvin, D. A. .1987. Managing Quality. New York: The Free Press

Ghozali, Imam. 2016. Aplikasi Analisis Multivariete Dengan Program IBM SPSS 23 (Edisi 8). Cetakan ke VIII. Semarang : Badan Penerbit Universitas Diponegoro

Goldsmith, R.E. and Horowitz, D. (2006). Measuring Motivations For Online Opinion Seeking. Journal of Interactive Advertising, Vol. 6 No. 2, pp. 3-14.

Goyette, I (2010). e-WOM Scale: Word-of-Mouth Measurement Scale for e-Services Context, Canadian Journal of Administrative Sciences, 27(1), 5-23

Gruen, Thomas W., Osmonbekov, Talai, Czaplewski, Andrew J. (2006). EWOM : The Impact of Customer-To-Customer Online Know-How Exchange on Customer Value and Loyalty. Journal of Business Research

Gruen,T.W et al .2006. e-WOM: The Impact Of Customer-To-Customer Online Knowhow Exchange On Customer Value And Loyalty. Journal Of Business Research. Vol 59, No 4

Hahn, Fred E. 2002. Beriklan dan Berpromosi Sendiri. Jakarta : PT. Gramedia Pustaka Utama

Hening-Thurau, Thorsten, Kevin P. Gwinner, Gianfranco Walsh, and Dwayne D. Gremler. 2004. Electronic Word of Mouth via Consumer Opinion Platforms: What Motivates Consumers to Articulate Themselves on The Internet. Journal of Interactive Marketing, 18 (1) PP:3852

Herdyanto, Abraham. 2020. 8 Keunggulan OPPO dibanding Brand Lain, Bisa Fasilitasi Ganti HP Baru. Dikutip pada tanggal 07 Juli 2020. Website: https://www.idntimes.com/tech/gadget/abraham-herdyanto/kelebihan-keunggulan-oppodibandingkan-brand-smartphone-lain/8

Isnawati, Yulina. 2018. Analisis Pengaruh Citra Merek, Persepsi Harga, dan Persepsi Kualitas Produk terhadap Keputusan Pembelian. Undip

John C Mowen dan Minor. 2001. Perilaku Konsumen. Jakarta:Erlangga

Kacen, J.J., \& Lee, J.A. 2002. The Influence of Culture on Consumer Impulsive Buying Behavior. Journal of Consumer Psychology

Kodu, Sarini. 2013. Harga, Kualitas Produk dan Kualitas Pelayanan Pengaruhnya terhadap Keputusan Pembelian Mobil Toyota Avansa. Jurnal EMBA, Vol 1 No. 3 PP:1251-12510

Kotler, Philip \& Garry Armstrong. 2010. Prinsip-Prinsip Pemasaran, Jilid 1 dan 2 Edisi Kedua Belas. Jakarta : Erlangga

Kotler, Philip \& Keller K Lane. 2010. 14 Edition. Marketing Management. New Jersey : Pearson Presentice Hall.

Musak, Billy Dkk. 2018. Pengaruh Daya Tarik Iklan dan Kualitas Produk terhadap Keputusan Pembelian Kartu XL Axiata Paket Data di Lingkungan Fakultas Ekonomi dan Bisnis Universitas sam Ratulangi. Jurnal EMBA, Vol 6 No. 4 PP: 2948-2957 
Nurmayanti dan Pristiyono. 2016. Pengaruh Daya Tarik Iklan, Motivasi Konsumen, dan Kualitas Produk terhadap Keputusan Pembelian Mitsubishi Pajero Sport pada PT Sumatera Berlian Motor Tantrapat. Jurnal Ecobisma, Vol 3 No.1

Rahmawati, Linda Ayu. 2017. Pengaruh Diskon, Impulse Buying dan Interior Display terhadap Kepeutusan Pembelian pada Swalayan Ria Mart Campurdarat-Tulungagung. Jurnal Simki-Economic, Vol 1 No. 5

Robbins, Stephen P. and Mary Coulter. (2012).Management, Eleventh Edition, (United States of America: Pearson Education Limited)

Rusli, Cindy Arista. 2019. Pengaruh Penggunaan Media Sosial, Electronic Word of Mouth (eWOM) terhadap Keputusan Pembelian Konsumen dan dimediasi oleh Kepercayaan. Universitas Matana

Saidani, Basrah. 2013. Pengaruh Kualitas Produk dan Desain Produk terhadap Keputusan Pembelian Sepatu Olahraga Futsal Adidas di Wilayah Jakarta Timur. Jurnal RMSI, Vol 4 No. 2

Sari, Novita. 2017. Pengaruh Electronic Word of Mouth terhadap Keputusan Pembelian pada Toko Online Bukalapak.com. Jurnal Manajemen Magister, Vol 03 No. 01

Sari, Ratna Dwi Kartika. 2012. Analisis Pengaruh Kualitas Produk, Persepsi Harga, dan Word of Mouth Communication terhadap Keputusan Pembelian Mebel pada CV Mega Jaya Semarang. Undip

Schiffman dan Kanuk. 2007. Perilaku Konsumen. Edisi Kedua. Jakarta:PT. Indeks

Shoham, A. dan Brencic, M.M (2003). Compulsive Buying Behavior. Journal of Marketing Research, vol 20

Soewito, Yudhi. 2013. Kualitas Produk, Merek dan Desain Pengaruhnya terhadap Keputusan Pembelian Sepeda Motor Yamaha Mio. Jurnal EMBA, Vol 1 No 3 PP:218-229

Sugiyono. 2017. Metode Penelitian Bisnis. Bandung:Alfabeta

Sulistyawati, Praba. 2010. Analisis Pengaruh Citra Merek dan Kualitas Produk terhadap Keputusan Pembelian Laptop merek Acer di kota Semarang. Undip

Tampi, Daniel Dkk. 2016. Pengaruh Kualitas Produk, Persepsi Harga, Daya Tarik Iklan terhadap Keputusan Pembelian Sepeda Motor Honda Scoopy pada PT Daya Adicipta Wisesa. Jurnal EMBA, Vol 14 No. 1 PP:990-999

Tonu, Wijaya. 2011. Manajemen Kualitas Jasa. Jakarta : PT. Indeks

Weenas, Jackson R.S. 2013. Kualitas Produk, Harga, Promosi dan Kualitas Pelayanan Pengaruhnya terhadap Keputusan Pembelian Springbed Comforta. Jurnal EMBA, Vol 1 No. 4 PP:607-618

Yulinda, Rodita. 2018. Pengaruh Promosi, Diskon dan Impulse Buying terhadap Keputusan Pembelian pada Indomaret cabang Rungkut Menanggal kota Surabaya. Jurnal Manajemen Branchmarck, Vol 4 No. 1 